\title{
High levels of heavy metals in rice (Oryza sativa L.) from a typical E-waste recycling area in southeast China and its potential risk to human health
}

\author{
Jianjie $\mathrm{Fu}^{\mathrm{a}, \mathrm{b}}$, Qunfang Zhou ${ }^{\mathrm{a}}$, Jiemin Liu ${ }^{\mathrm{c}}$, Wei Liu ${ }^{\mathrm{a}}$, Thanh Wang ${ }^{\mathrm{a}}$, \\ Qinghua Zhang ${ }^{\mathrm{a}}$, Guibin Jiang ${ }^{\mathrm{a}, *}$ \\ ${ }^{a}$ State Key Laboratory of Environmental Chemistry and Ecotoxicology, Research Center for Eco-Environmental Sciences, Chinese Academy of Sciences, \\ P.O. Box 2871, Beijing 100085, China \\ ${ }^{\mathrm{b}}$ State Key Laboratory of Soil and Sustainable Agriculture, Institute of Soil Science, Chinese Academy of Sciences, Nanjing 210008, China \\ ${ }^{\mathrm{c}}$ School of Applied Science, University of Science and Technology Beijing, Beijing 100083, China
}

Received 13 September 2007; received in revised form 28 November 2007; accepted 30 November 2007

Available online 4 March 2008

\begin{abstract}
Very few studies have investigated the heavy metal contents in rice samples from a typical E-waste recycling area. In this study, 10 heavy metals ( $\mathrm{As}, \mathrm{Ba}, \mathrm{Cd}, \mathrm{Co}, \mathrm{Cr}, \mathrm{Cu}, \mathrm{Hg}, \mathrm{Mn}, \mathrm{Ni}$ and $\mathrm{Pb}$ ) in 13 polished rice and relevant hull samples, six relevant paddy soil samples were investigated. The geometric mean concentrations of $\mathrm{Cd}, \mathrm{Cu}$ and $\mathrm{Hg}$ in soil samples were $1.19,9.98$ and $0.32 \mu \mathrm{g} \mathrm{g}^{-1}$, respectively, which were 4.0, 2.0 and 1.1-folds of the maximum allowable concentration (MAC) $\left(0.30,50.00,0.30 \mu \mathrm{g} \mathrm{g}^{-1}\right.$, respectively) for Chinese agricultural soils. The analyzed metal concentrations were significantly different between rice and relevant hull except for As, $\mathrm{Cd}$ and $\mathrm{Hg}(p<0.05)$. All metal concentrations, except for $\mathrm{Co}$, in rice hull were higher than those in polished rice. The geometric mean of $\mathrm{Pb}$ in polished rice reached $0.69 \mu \mathrm{g} \mathrm{g}^{-1}$, which was 3.5 -folds higher than the MAC $\left(0.20 \mu \mathrm{g} \mathrm{g}^{-1}\right)$ by the safety criteria for milled rice. Cd contents in $31 \%$ of the rice samples exceeded the national MAC $\left(0.20 \mu \mathrm{g} \mathrm{g}^{-1}\right)$, and the arithmetic mean also slightly exceeded national MAC. In addition, $\mathrm{Cd}$ and $\mathrm{Pb}$ contents in local rice were much higher than commercial rice samples examined in this work and previous studies. Comparing the tolerable daily intakes given by FAO/WHO with the mean estimated daily intakes; $\mathrm{Pb}$ daily intake through rice consumption in this area was $3.7 \mu \mathrm{g} \mathrm{day}^{-1} \mathrm{~kg}^{-1}$ body weight (bw), which already exceeded the FAO tolerable daily intake, and the Cd daily intake $\left(0.7 \mu \mathrm{g} \mathrm{day}^{-1} \mathrm{~kg}^{-1} \mathrm{bw}\right)$ through rice had already taken up $70 \%$ of the total tolerable daily intake $\left(1 \mu \mathrm{g} \mathrm{day}^{-1} \mathrm{~kg}^{-1} \mathrm{bw}\right)$. The daily intake of $\mathrm{Hg}$ and As through rice was much lower than the tolerable daily intakes, but bioaccumulation of $\mathrm{Hg}$ through the food chain and intake of As from other food stuff should also be of concern.
\end{abstract}

(C) 2007 Elsevier Ltd. All rights reserved.

Keywords: E-waste recycling; Heavy metals; Rice; Paddy soil; Estimated daily intakes (EDI); Tolerable daily intakes (TDI)

\section{Introduction}

The disposal of electronic and electric waste (E-waste) has caused a serious environmental problem, especially in developing countries. In China, rapidly increasing amount of E-waste from both domestic generation and illegal imports (UNEP, 2005; Widmer et al., 2005) should be men-

\footnotetext{
* Corresponding author. Tel.: +86 1062849334 ; fax: +861062849179 E-mail address: gbjiang@rcees.ac.cn (G. Jiang).
}

tioned. Since 1990s, a large amount of E-waste have been dismantled in Taizhou, Zhejiang Province, which is a well-known E-waste recycling centre in southeast China (Hicks et al., 2005; Zhao et al., 2006, 2007). Hundreds of small and open specialized E-waste recycling shelters or yards appear in this area. Many toxic ingredients such as lead, cadmium, beryllium, mercury, polychlorinated biphenyls and brominated flame retardants contained in these Ewastes, (Schmidt, 2002; Soderstrom and Marklund, 2002; Jang and Townsend, 2003; Wong et al., 2007) may enter 
into the environment and impose great threat to human health regardless of occupational and environmental exposure. The unregulated processing of E-waste usually recovers gold and other valuable metals by applying some simple techniques such as burning, melting, using acid chemical bath, and so on. These activities can cause severe pollution of highly toxic heavy metals (such as $\mathrm{Cu}, \mathrm{Cd}, \mathrm{Pb}$ and $\mathrm{Hg}$ ) in aquatic and terrestrial ecosystems, and even to the atmosphere (Deng et al., 2006; Leung et al., 2006). Heavy metals are non-biodegradable, thus persisting for long periods in environmental ecosystems.

Soils contaminated by heavy metals from either aerial depositions or irrigation are likely to induce a corresponding contamination in harvested crops (Nan et al., 2002). Crops in or close to contaminated sites can uptake and accumulate these metals, and then exert potential risk to humans and animals (Gupta and Gupta, 1998; Järup, 2003). Malfunction of organs and chronic syndromes may be caused by ingestion of relatively low doses of toxic heavy metals over a long period. The major route for heavy metals exposure to humans is mainly through soil-crop-food pathway. The residual plant components, including hull, straw and the root are partly returned to the soil and partly used as an ingredient in food for livestock, which is also a possible pathway for heavy metals to enter the human body by ingesting contaminated food.

In our study area, the E-waste dismantling sites are usually situated in rural areas, and crops are grown around these areas. Recent works have studied the contamination of persistent organic pollutants such as polychlorinated biphenyls and organochlorine pesticides (Zhao et al., 2006, 2007) in local food such as rice seeds, hen eggs, and silver carp muscle. To our knowledge, very few studies have investigated the heavy metal contents in crops collected from E-waste dismantling areas and conducted the corresponding risk assessment. According to statistical data from the Food and Agriculture Organization (FAO) (2004), rice nearly provides $30 \%$ of the dietary energy supply and $20 \%$ of the dietary protein intake around the world. As rice is a staple food for daily consumption in China, especially in the region of our study site, heavy metals in rice may contribute a major part to the FAO total daily intake. Therefore, there is an increasing requirement for the study of heavy metal levels in rice sampled from E-waste areas.

Four heavy metals, $\mathrm{As}, \mathrm{Cd}, \mathrm{Hg}$ and $\mathrm{Pb}$, were chosen for risk assessment because of their high toxicities or comparatively high levels in all of the collected rice samples. It is therefore necessary to determine the dose level for human, which is considered to be taken daily over a lifetime without adverse effects. Inorganic arsenic, a human carcinogen, is the most toxic form of arsenic. Cadmium is toxic to the kidney and has a long biological half-life in human. Lead has shown to be associated with damnification of central nervous system, leading to decrements of intelligence quotients in children. Mercury, particularly in its organic form, mainly exhibit neurotoxicity and teratogenicity (Baars et al., 2001).

In this study, the extent of heavy metal contamination in rice (Oryza sativa L.) was investigated, and relevant agricultural soils were collected from a typical E-waste recycling area, Taizhou in Zhejiang Province, southeast China. The relationship between polished rice and hull, in regards to heavy metal contents, was also discussed. Assessments of the daily dietary exposures of these metals to the local population through consumption of rice were also calculated. By comparing with the provisional tolerable weekly intakes (PTWIs) for heavy metals defined by FAO/WHO (WHO, 1993), the potential risk to the health of local inhabitants was then evaluated.

\section{Materials and methods}

\subsection{Site description and samplings}

Taizhou is the biggest E-waste recycling area in Zhejiang Province, which is located in southeast of China. The latitude and longitude of this site is $28.3^{\circ} \mathrm{N}$ and $121.2^{\circ} \mathrm{E}$. Ewaste and transformers have been illicitly processed or simply incinerated in small-sized waste metal treatment factories in the region since 1989. The corresponding environmental pollution is becoming more and more serious. Taizhou is also an important agricultural area in Zhejiang Province and rice serves as the major crop for the local people.

A total of 13 rice samples (TBI-1-TBI-13) and 6 soil (TSO-1-TSO-6) samples were collected directly from the contaminated rice paddies in November 2005. Each individual rice sample was composed of at least five sub-samples which were taken from the same rice paddy. Each topsoil sample $(0-20 \mathrm{~cm})$ was obtained by mixing at least five adjacent sub-samples from one paddy field (four corners and the centre; approximately $10 \times 10 \mathrm{~m}^{2}$ ). In addition, we analyzed four commercial rice samples bought from supermarkets as references in this study, which were from non-E-waste recycling areas.

The polished rice and its hull were separated by a decorticating machine. All samples (including rice and soil samples) were dried at $-52{ }^{\circ} \mathrm{C}$ under a pressure of 0.05 bar for $48 \mathrm{~h}$, then grinded to fine powder and sealed in polyethylene bottles.

\subsection{Sample analysis}

Approximately $0.2 \mathrm{~g}$ of plant and soil samples were weighed and put into a PTFE digestion container. Three millilitre of concentrated nitric acid (Merck, Germany) was added to each container and the samples were predigested overnight at $60{ }^{\circ} \mathrm{C}$. After cooling, $2 \mathrm{ml}$ of $30 \%$ hydrogen peroxide (Beijing Chemical Company, China) was added. The container was placed in a stainless steel bomb, and then sealed with a screw closure to avoid any acid leakage and placed in an oven. The oven temperature 
was kept for $1 \mathrm{~h}$ at $60{ }^{\circ} \mathrm{C}$ then increased to $160{ }^{\circ} \mathrm{C}$ for another $8 \mathrm{~h}$. After cooling to room temperature, the solution was transferred into a 25-ml PET bottle and diluted with Milli-Q water. Reagent blanks were processed simultaneously to deduct the error induced by the analytical procedure.

As, $\mathrm{Ba}, \mathrm{Cd}, \mathrm{Co}, \mathrm{Cr}, \mathrm{Cu}, \mathrm{Mn}, \mathrm{Ni}$, and $\mathrm{Pb}$ were measured by an inductively coupled plasma mass spectrometer (ICPMS) (Thermo 7 series, USA), while Hg was determined by an atomic fluorescence spectrometer (AFS) (AF-620, Beijing Rayleigh Analytical Instrument Company, China) after hydride generation. The instrumental parameters are listed in Table 1.

\subsection{Quality assurance and quality control}

Standard reference materials (SRM), including soil from a contaminated area (GBW08303), rice flour (GBW08502), and $\mathrm{Hg}$ content in rice flour (GBW08508), were used for validation of the analytical procedure. The heavy metal contents found in the SRMs were in good agreement with the certificate values, which confirmed the feasibility of the analytical protocols in the determination of heavy metals in rice and soil (Table 2). All analyses were performed in triplicates using the external calibration method.

\subsection{Tolerable daily intake of $\mathrm{As}, \mathrm{Cd}, \mathrm{Hg}$ and $\mathrm{Pb}$}

The PTWIs (UNEP, 1992; WHO, 1993) which was recommended by the Joint FAO/WHO Expert Committee on Food Additives (JECFA) showed appropriate safe exposure levels, which were used to estimate the amount of contaminants ingested over a lifetime without appreciable risk. The tolerable daily intakes (TDIs) of toxic metals such as $\mathrm{As}, \mathrm{Cd}, \mathrm{Hg}$ and $\mathrm{Pb}$ in this study were calculated according to the FAO/WHO's PTWIs.

\subsection{Estimated daily intake (EDI) of heavy metals through rice consumption}

The daily intake of metals depends on both the metal concentration in food and the daily food consumption. In addition, the body weight of the human can influence the tolerance of pollutants. The estimated daily intakes (EDI) is a concept introduced to take into account these factors. The EDI was calculated as follows:

$\mathrm{EDI}=\frac{C \times \text { Cons }}{\mathrm{Bw}}$

where $C$ is the concentration of the heavy metals in contaminated rice, Cons stands for the daily average consumption of rice in this region, and $\mathrm{Bw}$ represents the body weight. Based on the dietary nutrition intake level survey by Zhong et al. (2006), rice was the staple food for daily consumption, and the adult residents in this region had an average daily intake of $323 \mathrm{~g}$ rice per day. Their body weight was set to $60 \mathrm{~kg}$ in this study.

\subsection{Statistical analysis}

All the results were expressed on a dry weight basis. Past reports observed a log-normal distribution for heavy metals in environmental samples such as rice and soil (Watanabe et al., 1996; Zhang et al., 1996). Thus, geometric means (GM) and geometric standard deviations (GSD) were taken as representative parameters of distribution. ANOVA was applied to detect significant differences. The correlation analysis was conducted by Pearson correlation. Correlation is significant at the 0.05 level (two-tailed). All statistical analyses were performed with SPSS 13.0 for Windows release 13.0 (September 1, 2004, SPSS Inc., 1989-2004).

\section{Results and discussion}

\subsection{Heavy metal concentrations in soils}

The extent of soil contamination was evaluated by comparing the total concentrations of the involved heavy metals in soils from this area with the background values of Zhejiang Province (State environmental protection administration of China, 1993) and the maximum allowable concentrations (MAC) (GB15618-1995) of metals in agricultural soil of China. The $\mathrm{pH}$ values of the soil were related with the speciation and bioavailability of the heavy metals, thus the MAC in soil varied with the soil $\mathrm{pH}$. The

Table 1

Instrumental parameters

\begin{tabular}{|c|c|c|c|c|c|}
\hline \multicolumn{4}{|l|}{ ICP-MS } & \multicolumn{2}{|l|}{ AFS } \\
\hline Plasma power & $1300 \mathrm{~W}$ & Anal & & Hollow cathode lamp & $253.7 \mathrm{~nm}$ \\
\hline \multirow[t]{2}{*}{ Scanning mode } & Peak & As & 75 & PMT voltage & $280 \mathrm{~V}$ \\
\hline & Jump & $\mathrm{Ba}$ & 137 & & \\
\hline Channels per AMU & 3 & $\mathrm{Cd}$ & 111 & Primary current & $40 \mathrm{~mA}$ \\
\hline Gas flow rate $/ 1 \mathrm{~min}^{-1}$ & & Co & 59 & Carrier gas & Ar, $0.81 \mathrm{~min}^{-1}$ \\
\hline Auxiliary & 0.7 & $\mathrm{Cr}$ & 52 & Hydride generation & \\
\hline Cool & 13 & $\mathrm{Cu}$ & 65 & $\mathrm{KBH}_{4}$ concentration & $0.2 \%(\mathrm{~m} / \mathrm{v})$ \\
\hline Nebuliser & 0.89 & $\mathrm{Mn}$ & 55 & $\mathrm{HCl}$ & $1.2 \mathrm{~mol}^{-1}$ \\
\hline \multirow[t]{2}{*}{ Internal standard } & ${ }^{103} \mathrm{Rh}$ & $\mathrm{Ni}$ & 60 & Sampling time & $2 \mathrm{~s}$ \\
\hline & & $\mathrm{Pb}$ & 208 & Hydride generation time & $18 \mathrm{~s}$ \\
\hline
\end{tabular}


Table 2

Analysis of SRMs

\begin{tabular}{|c|c|c|c|c|c|c|c|c|c|}
\hline \multirow[b]{2}{*}{ Element } & \multicolumn{3}{|l|}{ GBW08303 } & \multicolumn{3}{|l|}{ GBW08508 } & \multicolumn{3}{|l|}{ GBW08502 } \\
\hline & Certified value & $\begin{array}{l}\text { Measured value } \\
(\text { mean } \pm \mathrm{SD})^{\mathrm{a}}\end{array}$ & Recovery $(\%)$ & $\begin{array}{l}\text { Certified } \\
\text { value }\end{array}$ & $\begin{array}{l}\text { Measured value } \\
(\text { mean } \pm \mathrm{SD})\end{array}$ & Recovery (\%) & $\begin{array}{l}\text { Certified } \\
\text { value }\end{array}$ & $\begin{array}{l}\text { Measured value } \\
(\text { mean } \pm \mathrm{SD})\end{array}$ & Recovery $(\%)$ \\
\hline $\mathrm{As} / \mu \mathrm{g} \mathrm{g}^{-1}$ & $10.6 \pm 0.6$ & $10.6 \pm 1.7$ & 100 & $-\mathrm{b}$ & - & - & $0.051 \pm 0.003$ & $0.052 \pm 0.007$ & 101 \\
\hline $\mathrm{Cd} / \mu \mathrm{g} \mathrm{g}^{-1}$ & $1.2 \pm 0.07$ & $1.3 \pm 0.1$ & 108 & - & - & - & $0.020 \pm 0.002$ & $0.017 \pm 0.001$ & 85 \\
\hline $\mathrm{Cr} / \mu \mathrm{g} \mathrm{g}^{-1}$ & $112 \pm 6$ & $94 \pm 2$ & 84 & - & - & - & & & - \\
\hline $\mathrm{Cu} / \mu \mathrm{g} \mathrm{g}^{-1}$ & $120 \pm 6$ & $117 \pm 0.6$ & 98 & $3.6 \pm 0.2$ & $3.6 \pm 0.02$ & 100 & $2.6 \pm 0.2$ & $2.4 \pm 0.03$ & 92 \\
\hline $\mathrm{Hg} / \mu \mathrm{g} \mathrm{g}^{-1}$ & $2.15 \pm 0.06$ & $2.07 \pm 0.36$ & 96 & $0.038 \pm 0.03$ & $0.045 \pm 0.002$ & 118 & - & - & - \\
\hline $\mathrm{Mn} / \mu \mathrm{g} \mathrm{g}^{-1}$ & $519 \pm 18$ & $498 \pm 9$ & 96 & $28.4 \pm 1.9$ & $27.8 \pm 0.1$ & 98 & $9.8 \pm 0.2$ & $9.5 \pm 0.1$ & 97 \\
\hline $\mathrm{Ni} / \mu \mathrm{g} \mathrm{g}^{-1}$ & $40 \pm 2$ & $37 \pm 1$ & 93 & - & - & - & - & - & - \\
\hline $\mathrm{Pb} / \mu \mathrm{g} \mathrm{g}^{-1}$ & $73 \pm 2$ & $72 \pm 0.6$ & 99 & - & - & - & $0.75 \pm 0.05$ & $0.81 \pm 0.01$ & 108 \\
\hline
\end{tabular}

a $n=3$.

b No certificated value.

$\mathrm{pH}$ values of soil samples in this site ranged from 4.93 to 5.66, which corresponded to Grade II of the Environmental quality standard for soils (GB15618-1995). As shown in Table 3, the GM of 10 metal elements (As, Ba, Cd, Co, Cr, $\mathrm{Cu}, \mathrm{Hg}, \mathrm{Mn}, \mathrm{Ni}$ and $\mathrm{Pb}$ ) were 4.07, 3.03, 1.19, 1.13, 6.12, $9.88,0.33,344.72,34.65$ and $55.81 \mu \mathrm{g} \mathrm{g}^{-1}$, respectively. $\mathrm{Cd}, \mathrm{Cr}, \mathrm{Cu}, \mathrm{Hg}, \mathrm{Ni}$ and $\mathrm{Pb}$ exceeded the corresponding background values by $8.4,1.1,4.7,2.3,1.3$ and 1.9-folds, respectively. In addition, $\mathrm{Cd}, \mathrm{Cu}$ and $\mathrm{Hg}$ exceeded the MAC levels $\left(0.20,50.00,0.20 \mu \mathrm{g} \mathrm{g}^{-1}\right.$, respectively) by 4.0 , 2.0 and 1.1-folds, respectively. The concentrations of $\mathrm{Cd}$ in soil samples were in the range of $0.55-7.86 \mu \mathrm{g} \mathrm{g}^{-1}$. This might indicate that point source pollutions existed in the sampling area. These results showed that the soil in this region was primarily contaminated by $\mathrm{Cd}$, followed by $\mathrm{Cu}$, whereas $\mathrm{Hg}$ pollution was not serious. Levels of $\mathrm{Pb}$, $\mathrm{Ni}$ and $\mathrm{Cr}$ exceeded the corresponding background value, but they were under the maximum allowable concentrations, indicating no serious contamination of these metals in this area.

\subsection{Heavy metal concentrations in polished rice and hull}

\subsubsection{Comparison of heavy metals in polished rice and hull}

Though only the inner rice part, so-called polished rice, is consumed by human, the hull part is usually consumed by livestock. Hazardous elements may also accumulate in human body through the food chain by consumption of these livestock. Ten heavy metals in polished rice and hull samples collected from the E-waste recycling area were determined. The results were shown in Fig. 1. In the layout, the horizontal line in the box represents the median value and the vertical bars display the range of the data. The concentrations of metals other than $\mathrm{As}, \mathrm{Cd}$ and $\mathrm{Hg}$ in polished rice were significantly different from those in the hull $(p<0.05)$ (Fig. 1a). Generally, the metal concentrations in hull were higher than those in the polished rice (Fig. 1b). The concentrations of $\mathrm{Ba}, \mathrm{Cu}, \mathrm{Mn}, \mathrm{Ni}$ and $\mathrm{Pb}$ in the hull were $1.9,3.4,8.4,11.6$ and 6.3 -folds higher than those in the polished rice. Moreover, metals in polished rice and hull had low correlation with those in the soil samples, which differed from previous results (Cao and $\mathrm{Hu}, 2000$ ). It suggests that in this area, the accumulation of metals in the hull might partly come from aerial deposition. In this study, we found that Cr level in hull exceeded that in polished rice by as much as 253.7 -folds. In a survey of the heavy metal compositions in total suspended particles (TSP) in Guiyu, another E-waste recycling area, Deng et al. (2006) found that the most enriched metals were $\mathrm{Cr}, \mathrm{Zn}, \mathrm{Pb}$ and $\mathrm{Cu}$, and the occurrence of metals generally ranked in the order $\mathrm{Cr}>\mathrm{Zn}>\mathrm{Pb}>\mathrm{Cu}>\mathrm{Mn}>\mathrm{Cd}>$ $\mathrm{Ni}>$ As. This result partly confirms our deduction that aerial deposition contributed to higher contents of $\mathrm{Cr}, \mathrm{Pb}, \mathrm{Mn}$ and $\mathrm{Cu}$ in hull than in polished rice. The concentration of Co in rice was 1.7-fold higher than that in hull (Fig. 1c). Among the 10 elements analyzed, $\mathrm{Cd}, \mathrm{Mn}$ and $\mathrm{Hg}$ concentrations in polished rice were significantly correlated with those in hull $\left(R^{2}=0.867,0.629\right.$ and 0.845 , respectively).

Table 3

Comparison of total heavy metals contents in soil in Taizhou with background values and national MAC $\left(\mu \mathrm{g} \mathrm{g}^{-1}\right)$

\begin{tabular}{|c|c|c|c|c|c|c|c|c|c|c|}
\hline & As & $\mathrm{Ba}$ & $\mathrm{Cd}$ & Co & $\mathrm{Cr}$ & $\mathrm{Cu}$ & $\mathrm{Hg}$ & $\mathrm{Mn}$ & $\mathrm{Ni}$ & $\mathrm{Pb}$ \\
\hline TSO-01 & 3.22 & 340.13 & 0.79 & 12.54 & 71.26 & 111.78 & 0.30 & 362.95 & 41.57 & 54.41 \\
\hline TSO-02 & 5.58 & 301.43 & 0.65 & 9.91 & 55.92 & 83.80 & 0.76 & 391.78 & 27.63 & 64.56 \\
\hline TSO-03 & 3.91 & 350.00 & 7.02 & 13.77 & 74.12 & 183.97 & 0.24 & 358.97 & 52.67 & 51.98 \\
\hline TSO-05 & 4.61 & 285.26 & 7.86 & 10.98 & 63.38 & 236.89 & 0.35 & 239.72 & 46.19 & 51.96 \\
\hline TSO-06 & 4.60 & 295.09 & 0.55 & 10.76 & 59.95 & 108.06 & 0.37 & 438.64 & 30.43 & 58.20 \\
\hline$G M$ & 4.07 & 303.26 & 1.19 & 11.26 & 61.21 & 98.81 & 0.33 & 344.72 & 34.65 & 55.81 \\
\hline
\end{tabular}

\footnotetext{
a No relevant data.
} 

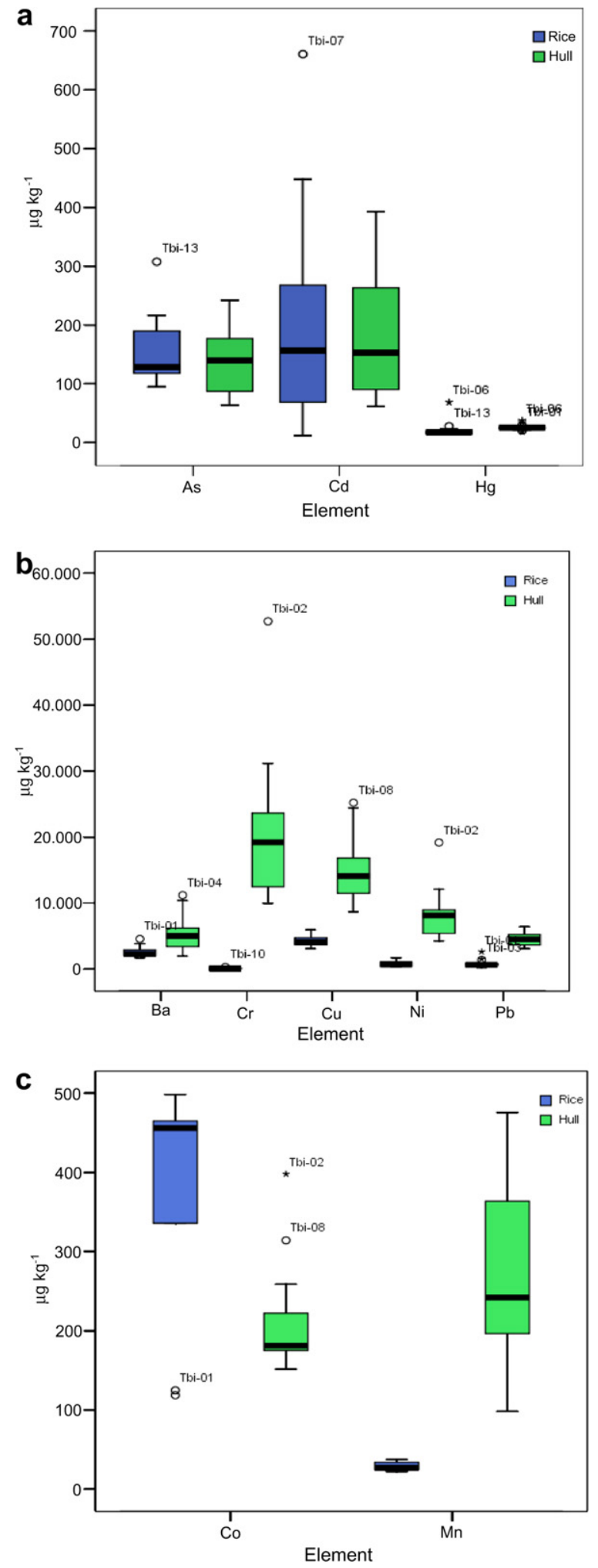

Fig. 1. (a) Box-and-whisker plots of $\mathrm{As}, \mathrm{Cd}$ and $\mathrm{Hg}$ contents in polished rice and hull which were not significantly different $\left(\mu \mathrm{g} \mathrm{kg}^{-1}\right)(p>0.05)$. (b) Box-and-whisker plots of $\mathrm{Ba}, \mathrm{Cr}, \mathrm{Cu}, \mathrm{Ni}$ and $\mathrm{Pb}$ concentration in polished rice and hull which were significant different $\left(\mu \mathrm{g} \mathrm{kg}^{-1}\right)(p<0.05)$. (c) Boxand-whisker plots of $\mathrm{Co}$ and $\mathrm{Mn}$ concentrations in polished rice and hull. The Co concentration in polished rice was higher than in hull $\left(\mu \mathrm{g} \mathrm{kg}^{-1}\right)$. $\mathrm{Mn}$ concentration in polished rice and hull was calculated in $\mu \mathrm{g} \mathrm{g}^{-1}$. In the layout, the horizontal line in the box represents the median and the vertical bars display the range of the data.
3.2.2. Comparison with national standards and other studies

Generally, GM illustrates more exact distribution of the element concentrations in rice samples, but comparison with many other studies is difficult due to the lack of information on GM. Of all the contaminated polished rice samples we measured, the highest concentrations of $\mathrm{Pb}, \mathrm{Cd}$, As, $\mathrm{Hg}$ were found to be $2.60,0.66,0.22$ and $0.07 \mu \mathrm{g} \mathrm{g}^{-1}$ respectively. Comparatively, the concentrations of toxic elements, such as $\mathrm{Cd}, \mathrm{Ba}$ and $\mathrm{Pb}$, in rice collected from Taizhou are apparently higher than those from other areas. The GM concentration of Ba reached $2.47 \mu \mathrm{g} \mathrm{g}^{-1}$, which was approximately five times higher than the four control samples employed in this study. Moreover, the maximum concentration of $\mathrm{Ba}$ in four commercial rice samples was even lower than the minimum concentration in the Taizhou samples (Table 4). Further, the $\mathrm{Cd}$ and $\mathrm{Pb}$ concentrations in Taizhou rice were approximately 8-fold and 4-fold greater than those found in rice from other areas. The concentrations of other toxic elements ( $\mathrm{As}, \mathrm{Hg}, \mathrm{Cu}$ and $\mathrm{Cr}$ ) in Taizhou rice fall within the range of previous studies. According to the national standard for safety milled rice criteria (NY5115-2002), the maximum allowable concentrations (MAC) of $\mathrm{As}, \mathrm{Cd}, \mathrm{Pb}$ and $\mathrm{Hg}$ are 0.50, 0.20, 0.20 and $0.02 \mu \mathrm{g} \mathrm{g}^{-1}$, respectively. In this study, the $\mathrm{Cd}$, $\mathrm{Pb}$, and $\mathrm{Hg}$ contents in $31 \%, 100 \%$, and $15.3 \%$ of the rice samples from Taizhou exceeded the national standards. The GM of $\mathrm{Pb}$ for the 13 samples was $0.69 \mu \mathrm{g} \mathrm{g}^{-1}$, which exceeded the MAC $\left(0.20 \mu \mathrm{g} \mathrm{g}^{-1}\right)$ by 3.5 -folds. The GM of Cd did not exceed the MAC $\left(0.20 \mu \mathrm{g} \mathrm{g}^{-1}\right)$, but arithmetic mean $\left(0.23 \mu \mathrm{g} \mathrm{g}^{-1}\right)$ slightly exceeded the limit. Table 4 shows detailed results for the heavy metal contents in the rice samples were summarized and compared with those found in some previous studies. These results indicated that rice from Taizhou was most seriously polluted by $\mathrm{Pb}$, followed by $\mathrm{Cd}$ and $\mathrm{Ba}$. It has been reported that E-waste contains abundant $\mathrm{Pb}, \mathrm{Ba}$ and $\mathrm{Cd}$, but their recycling efficiencies were only $5 \%, 0 \%$ and $0 \%$, respectively (Puckett and Smith, 2002). The erosion of these metals from E-waste recycling activities could be discharged into the peripheral environment, thus it should not be a surprise that rice from this area was seriously contaminated with these elements.

\subsection{Human exposure to metals through rice}

Local inhabitants who consume rice grown in this area are exposed to heavy metal contamination. The comparison of EDI with TDI for four elements; As, $\mathrm{Cd}, \mathrm{Hg}$ and $\mathrm{Pb}$, are shown in Table 5.

We assumed that the local population consumes the local rice, and the EDI that was calculated from Eq. (1) is based on heavy metal levels from the rice samples. The EDI of $\mathrm{Cd}$ by the local population was calculated to $0.7 \mu \mathrm{g} \mathrm{day}^{-1} \mathrm{~kg}^{-1} \mathrm{bw}$, which corresponds to $70 \%$ of the TDI $\left(1 \mu \mathrm{g} \mathrm{day}^{-1} \mathrm{~kg}^{-1}\right.$ bw). The maximum daily intake of $\mathrm{Cd}$ from rice was $3.6 \mu \mathrm{g}$ day ${ }^{-1} \mathrm{~kg}^{-1}$ bw (calculated from the maximum concentrations of $\mathrm{Cd}$ in rice) in Taizhou, which was 3.6-fold higher than TDI. On the other hand, 
Table 4

Comparison of the mean and range concentrations $(\mathrm{ng} / \mathrm{g})$ of the studied rice sample with data available from some previous studies

\begin{tabular}{|c|c|c|c|c|c|c|c|c|}
\hline Element & Area & $\mathrm{N}$ & $\mathrm{AM}(\mathrm{a})$ & ASD (b) & GM (c) & GSD (d) & Min & $\operatorname{Max}$ \\
\hline \multirow[t]{4}{*}{ As } & Taizhou & 13 & 154.7 & 58.5 & 146.6 & 1.4 & 94.7 & 307.6 \\
\hline & Commercial rice, China & 4 & 69.5 & 34.9 & 64.3 & 1.5 & 46.9 & 121.5 \\
\hline & Vietnam (e) & 31 & 208 & - & - & - & 32 & 465 \\
\hline & Bangladesh (f) & 4 & 11.3 & 7.6 & - & - & $<5$ & 20.2 \\
\hline \multirow[t]{2}{*}{$\mathrm{Ba}$} & Taizhou & 13 & 2586.8 & 875.0 & 2472.1 & 1.4 & 1662.6 & 4535.5 \\
\hline & Commercial rice in China & 4 & 715.7 & 562.5 & 526.2 & 2.6 & 161.6 & 1395.2 \\
\hline \multirow[t]{3}{*}{$\mathrm{Cd}$} & Taizhou & 13 & 224.0 & 195.6 & 125.2 & 3.3 & 11.7 & 660.7 \\
\hline & Commercial rice in China & 4 & 34.5 & 34.5 & 17.3 & 4.6 & 3.6 & 69.7 \\
\hline & Hangzhou (g) & 5 & 31.8 & 36.7 & 17.2 & 3.6 & trace & 92 \\
\hline \multirow[t]{3}{*}{$\mathrm{Cu}$} & Taizhou & 13 & 4259.9 & 825.7 & 4189.1 & 1.2 & 3036.6 & 5184.1 \\
\hline & Commercial rice in China & 4 & 3325.9 & 773.9 & 3266.3 & 1.2 & 2811.9 & 4477.9 \\
\hline & Vietnam (e) & 31 & 2600 & - & - & - & 1100 & 5800 \\
\hline \multirow[t]{3}{*}{$\mathrm{Pb}$} & Taizhou & 13 & 2042.2 & 2069.7 & 690.4 & 1.8 & 256.3 & 2601.7 \\
\hline & Commercial rice in China & 4 & 355.5 & 266.8 & 333.9 & 1.8 & 166.7 & 745.4 \\
\hline & Hangzhou (g) & 5 & 131.2 & 102.6 & 106.6 & 2.01 & 45 & 308 \\
\hline \multirow[t]{4}{*}{$\mathrm{Ni}$} & Taizhou & 13 & 761.3 & 391.3 & 676.1 & 1.7 & 339.4 & 1134.4 \\
\hline & Commercial rice in China & 4 & 475.8 & 276.2 & 413.9 & 1.9 & 201.4 & 818.4 \\
\hline & Vietnam (e) & 31 & 869 & - & - & - & $<100$ & 2022 \\
\hline & Australia (e) & 11 & 134 & - & - & - & $<100$ & 204 \\
\hline \multirow[t]{3}{*}{$\mathrm{Mn}$} & Taizhou & 13 & 28639.9 & 5570.3 & 28157.2 & 1.2 & 21977.0 & 37489.7 \\
\hline & Commercial rice in China & 4 & 9363.1 & 3288.1 & 8908.9 & 1.4 & 5804.3 & 12707.5 \\
\hline & Vietnam (e) & 31 & 9900 & - & - & - & 5900 & 16300 \\
\hline \multirow[t]{2}{*}{$\mathrm{Hg}$} & Taizhou & 13 & 22.0 & 14.5 & 19.7 & 1.5 & 15.6 & 68.4 \\
\hline & Commercial rice in China & 4 & 28.8 & 5.6 & 28.4 & 1.2 & 24.4 & 36.4 \\
\hline \multirow[t]{2}{*}{$\mathrm{Cr}$} & Taizhou & 13 & 106.8 & 83.2 & 75.3 & 2.7 & 6.0 & 279.4 \\
\hline & Commercial rice in China & 4 & 199.3 & 157.1 & 158.3 & 2.2 & 62.0 & 424.4 \\
\hline \multirow[t]{2}{*}{ Co } & Taizhou & 13 & 386.9 & 131.5 & 354.4 & 1.6 & 118.6 & 498.3 \\
\hline & Commercial rice in China & 4 & 169.4 & 169.7 & 121.7 & 2.5 & 55.0 & 419.5 \\
\hline
\end{tabular}

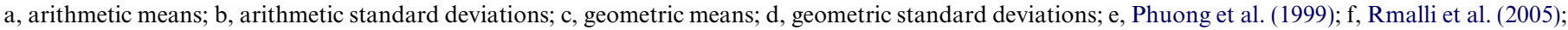
g, Cheng et al. (2006); others obtained in this study.

some individuals in this area may consume more than twice of the average amount of rice, and their daily dietary intakes of $\mathrm{Cd}$ would further exceed the TDI. Chronic $\mathrm{Cd}$ poisoning due to rice-mediated environmental exposure induced the Itai-itai disease in Japan in 1960s. The disease, which is characterized by osteomalacia with simultaneous renal dysfunction, has been well documented. Though the $\mathrm{Cd}$ concentration in Taizhou rice was slightly lower than that in Japan (Nogawa et al., 2004), attention still needs to be paid. The TDI for $\mathrm{Pb}$ was set by the JECFA (WHO, 1993) at $3.6 \mu \mathrm{g} \mathrm{day}^{-1} \mathrm{~kg}^{-1}$ bw. The dietary intakes for the local population ranged from 1.4 to $14.0 \mu \mathrm{g}$ day${ }^{1} \mathrm{~kg}^{-1}$ bw with a mean value at $3.7 \mu \mathrm{g} \mathrm{day}^{-1} \mathrm{~kg}^{-1}$ bw. Five out of 13 samples $(38.5 \%)$ exceed the TDI. Moreover, the EDI here was only evaluated for $\mathrm{Cd}$ and $\mathrm{Pb}$ in rice, which accounts for only a fraction of the contamination through daily dietary consumption. If taking the whole contamination through dietary into consideration, the $\mathrm{Cd}$ and $\mathrm{Pb}$ dietary exposure for the local population in this area would probably reach unsound levels. Huo et al. (2007) have recently reported elevated $\mathrm{Pb}$ levels in blood samples from children in Guiyu, another E-waste recycling center in China. Our metal analysis results suggest that this phenomenon may recur in Taizhou partly due to the heavy contamination of $\mathrm{Pb}$ in rice, though this needs further study. As a result, daily intake of rice or crops grown in this area might cause detrimental health hazards to the consumers.
Table 5

Mean estimated daily intake by a $60 \mathrm{~kg}$ body weight person and the range in Taizhou

\begin{tabular}{lrllllr}
\hline Element & TDI & MEDI & \%TDI & \% E-TDI & MinI & MaxI \\
\hline $\mathrm{As}$ & 50.0 & 0.8 & 1.6 & 0.0 & 0.5 & 1.7 \\
$\mathrm{Cd}$ & 1.0 & 0.7 & 67.4 & 38.5 & 0.1 & 3.6 \\
$\mathrm{Hg}$ & 0.7 & 0.1 & 14.7 & 0.0 & 0.1 & 0.4 \\
$\mathrm{~Pb}$ & 3.6 & 3.7 & 103.2 & 38.5 & 1.4 & 14.0 \\
\hline
\end{tabular}

TDI: tolerable daily intake $\left(\mu \mathrm{g}\right.$ day $\left.^{-1} \mathrm{~kg}^{-1} \mathrm{bw}\right)$.

MEDI: mean (GM) estimated daily intake $\left(\mu \mathrm{g} \mathrm{day}{ }^{-1} \mathrm{~kg}^{-1} \mathrm{bw}\right)$.

MinI: estimated minimum daily intake ( $\left.\mu \mathrm{g} \mathrm{day}{ }^{-1} \mathrm{~kg}^{-1} \mathrm{bw}\right)$.

MaxI: estimated maximum daily intake $\left(\mu \mathrm{g} \mathrm{day}^{-1} \mathrm{~kg}^{-1} \mathrm{bw}\right)$.

$\%$ E-TDI: represents the percentage of heavy metal in rice samples which exceed the TDI.

\section{Conclusion}

From the results of the rice and soil samples gathered from this study, we obtained a better knowledge regarding the impact of E-waste recycling activities on the environment and the potential risk to human health. Based on the data obtained to date, the agricultural soil in Taizhou was most severely contaminated by $\mathrm{Cd}$, followed by $\mathrm{Cu}$ and $\mathrm{Hg}$. The levels of $\mathrm{Pb}, \mathrm{Ni}$ and $\mathrm{Cr}$ exceeded the corresponding background values, but were below the national MAC, implicating no serious contamination of these elements in this area. Low correlations among the polished rice, hull and soil and the high metal contents detected in 
hull suggested that aerial deposition is a potential source for metal contamination in rice. In regards to the national food safety criteria, $\mathrm{Pb}$ content in all rice samples exceeded the national MAC. By estimating the daily intake of $\mathrm{Pb}$ by the local inhabitants, we concluded that the $\mathrm{Pb}$ daily intake in this area might exceed the TDI recommended by FAO. $\mathrm{Cd}$ content in rice from this area was much higher than those from other areas and those of previous studies, which further imply that high $\mathrm{Cd}$ contamination exists in $\mathrm{E}$ wastes recycling areas. Although the mean estimated daily intake of $\mathrm{Cd}$ from rice is $70 \%$ of the TDI, it still holds a high proportion of TDI, suggesting local rice consumption may induce excessive $\mathrm{Cd}$ intake as well. Also, both As and $\mathrm{Hg}$ contamination through rice should not be neglected, though their mean EDIs were lower than TDI. However, the consumption of rice accompanying with other local contaminated foods such as meat, milk, and crop will probably contribute to elevated levels of both metals. As a whole, long term consumption of the local rice may bear high risk of heavy metal exposure to the consumer. This caution should not only concern the local residents around the E-waste center but also extend to people living in downstream or downwind of this area. Moreover, a great deal of attention should also be paid regarding the contamination of biota through the food chain. Relevant data are still limited and further studies need to be conducted.

\section{Acknowledgements}

This study was supported by Foundation of the State Key Laboratory of Soil and Sustainable Agriculture (20607025), Chinese Academy of Sciences (KJCX2-YW-H04), and Natural Science Foundation of China (40590392).

\section{References}

Baars, A., Theelen, R., Janssen, P., Hesse, J., van Apeldoorn, M., Meijerink, M., Verdam, L., Zeilmaker, M., 2001. Re-evaluation of human toxicological maximum permissible risk levels. RIVM Report 711701025 .

Cao, Z., Hu, Z., 2000. Copper contamination in paddy soils irrigated with wastewater. Chemosphere 41, 3-6.

Cheng, F., Zhao, N., Xu, H., Li, Y., Zhang, W., Zhu, Z., Chen, M., 2006. Cadmium and lead contamination in japonica rice grains and its variation among the different locations in southeast China. Sci. Total Environ. 359, 156-166.

Deng, W., Louie, P., Liu, W., Bi, X., Fu, J., Wong, M., 2006. Atmospheric levels and cytotoxicity of PAHs and heavy metals in TSP and PM2 5 at an electronic waste recycling site in southeast China. Atmos. Environ. 40, 6945-6955.

Environmental quality standard for soils (GB15618-1995). State environmental protection administration of China (in Chinese).

FAO, 2004. FAOSTAT, FAO Statistical Databases. http://apps.fao.org/.

Gupta, U., Gupta, S., 1998. Trace element toxicity relationships to crop production and livestock and human health: implications for management. Commun. Soil. Sci. Plant Anal. 29, 1491-1522.

Hicks, C., Dietmar, R., Eugster, M., 2005. The recycling and disposal of electrical and electronic waste in China-legislative and market responses. Environ. Impact Asses. Rev. 25, 459-471.

Huo, X., Peng, L., Xu, X., Zheng, L., Qiu, B., Qi, Z., Zhang, B., Han, D., Piao, Z., 2007. Elevated blood lead levels of children in Guiyu, an electronic waste recycling town in China. Environ. Health Perspect. $115,1113-1117$.

Jang, Y., Townsend, T., 2003. Leaching of lead from computer printed circuit boards and cathode ray tubes by municipal solid waste landfill leachates. Environ. Sci. Technol. 37, 4778-4784.

Järup, L., 2003. Hazards of heavy metal contamination. Brit. Med. Bull. 68, 167-182.

Leung, A., Cai, Z., Wong, M., 2006. Environmental contamination from electronic waste recycling at Guiyu, southeast China. J. Mater. Cycles. Waste. Manag. 8, 21-33.

Nan, Z., Zhao, C., Li, J., Chen, F., Sun, W., 2002. Relations between soil properties and elected heavy metal concentrations in spring wheat (Triticum aestivum L.) grown in contaminated soils. Water, Air, Soil Pollut. 133, 205-213.

National programme on safety food. Safety milled rice criteria of PR China (NY5115-2002). Beijing: China ministry of Agriculture; 2002 (in Chinese).

Nogawa, K., Kobayashi, E., Okubo, Y., Suwazono, Y., 2004. Environmental cadmium exposure, adverse effects and preventive measures in Japan. Biometals 17, 581-587.

Phuong, T., Van Chuong, P., Tong Khiem, D., Kokot, S., 1999. Elemental content of Vietnamese rice Part 1 Sampling, analysis and comparison with previous studies. Analyst 124, 553-560.

Puckett, J., Smith, T., 2002. Exporting harm: the high-tech trashing of Asia. The Basel Action Network (BAN) Silicon Valley Toxics Coalition (SVTC).

Rmalli, S., Haris, P., Harrington, C., Ayub, M., 2005. A survey of arsenic in foodstuffs on sale in the United Kingdom and imported from Bangladesh. Sci. Total Environ. 337, 23-30.

Schmidt, C., 2002. e-Junk explosion. Environ. Health Perspect. 110, A188-A194.

State environmental protection administration of China (Ed.), 1993. Research on Environmental Background Values and Environmental Capacities, Science press, China, pp. 10-14 (in Chinese).

Soderstrom, G., Marklund, S., 2002. PBCDD and PBCDF from incineration of waste-containing brominated flame retardants. Environ. Sci. Technol. 36, 1959-1964.

UNEP DEWA/GRID-Europe, 2005. E-waste, the hidden side of IT equipment's manufacturing and use. http://www.grid.unep.ch/product/publication/download/ew_ewaste.en.pdf.

UNEP/FAO/WHO, 1992. Assessment of dietary intake of chemical contaminants. United Nations Environmental Program, Nairobi.

Watanabe, T., Shimbo, S., Moon, C., Zhang, Z., Ikeda, M., 1996. Cadmium contents in rice samples from various areas in the world. Sci. Total Environ. 184, 191-196.

WHO, World Health Organization, 1993. Evaluation of certain food additives and contaminants (41st report of the joint FAO/WHO expert committee on food additives). WHO Tech. Reports Series No. 837.

Widmer, R., Oswald-Krapf, H., Sinha-Khetriwal, D., Schnellmann, M., Böni, H., 2005. Global perspectives on e-waste. Environ. Impact Asses. Rev. 25, 436-458.

Wong, M., Wu, S., Deng, W., Yu, X., Luo, Q., Leung, A., Wong, C., Luksemburg, W., Wong, A., 2007. Export of toxic chemicals: a review of the case of uncontrolled electronic-waste recycling. Environ. Pollut. 149, 131-140.

Zhang, Z., Moon, C., Watanabe, T., Shimbo, S., 1996. Ikeda M. Lead contents of rice collected from various areas in the world. Sci. Total Environ. 191, 169-175.

Zhao, G., Xu, Y., Han, G., Ling, B., 2006. Biotransfer of persistent organic pollutants from a large site in China used for the disassembly of electronic and electrical waste. Environ. Geochem. Health 28, 341351.

Zhao, G., Xu, Y., Han, G., Ling, B., 2007. PCBs and OCPs in human milk and selected foods from Luqiao and Pingqiao in Zhejiang, China. Sci. Total Environ. 378, 281-292.

Zhong, J., Yu, M., Liu, L., Chen, Y., Hu, R., Gong, W., 2006. Study on the dietary nutrition intake level in Zhejiang Province. Dis. Surveillance 21 (12), 670-672 (in Chinese). 